\title{
Cutaneous Leishmaniasis in Pediatric Patients in a Single Tertiary Hospital in Ankara
}

\author{
Cocuklarda Kutanöz Leishmaniasis: Tek Merkez Deneyimi
}

\section{Ayşe Kaman¹, Gönül Tanır, Zeynep Gökçe Gayretli Aydın, Özge Metin¹, Türkan Aydın Teke, Fatma Nur Öz1, Mesut Mungan²}

1Division of Pediatric Infectious Diseases, Dr. Sami Ulus Maternity and Children's Training and Research Hospital, Ankara, Turkey

${ }^{2}$ National Reference Laboratory for Parasitology, Public Health Institution of Turkey, Ankara, Turkey

Cite this article as: Kaman A, Tanır G, Gayretli Aydın ZG, Metin Ö, Aydın Teke T, Öz FN, et al. Cutaneous Leishmaniasis in Pediatric Patients in a Single Tertiary Hospital in Ankara. Türkiye Parazitol Derg 2017; 41: 214-8.

\section{ABSTRACT}

Objective: Leishmaniasis is an infectious disease that is caused by a protozoan parasite of the Leishmania genus and that occurs worldwide. Leishmaniasis is endemic in southeastern Turkey and the neighboring Middle Eastern countries. The purpose of this study was to describe the clinical characteristics of patients admitted to our hospital with a diagnosis of cutaneous leishmaniasis (CL).

Methods: A total of 16 CL patients [11 (69\%) boys and five (31\%) girls] were admitted between January 2014 and December 2015. The data of the patients were retrospectively recorded from their medical records.

Results: Their mean age was $74.3 \pm 32.3$ months (range: $1-10.5$ years). Double lesions were most commonly seen in eight (50\%) patients. The face and neck was the most commonly involved site ( $87.5 \%$ of the patients). Skin smears for a parasitological examination were positive in nine (56\%) patients. Two patients (12.5\%) with limb lesions were treated with intralesional meglumine antimoniate. Fourteen patients were treated with systemic agents.

Conclusion: We felt that the increase in human movement that include travels and forced migration due to the war might make it possible for $C L$ to appear in non-endemic provinces such as Ankara. In particular, in patients with painless cutaneous lesion(s) who came from endemic areas such as Syria, CL should be kept in mind by the clinicians that residing in even non-endemic areas.

Keywords: Cutaneous leishmaniasis, children, refugees from Syria

Received: 03.03.2017

Accepted: 22.08 .2017

\section{Öz}

Amaç: Leishmaniasis, tüm dünyada görülen, Leishmania türlerinin etken olduğu paraziter bir enfeksiyon hastalığıdır. Leishmaniasis, Türkiye'nin Güney Doğu'sunda ve komşu Orta Doğu ülkelerinde endemiktir. Bu çalışma ile, Suriye'deki savaştan sonra hastanemize kutanöz leishmaniasis (KL) tanısı ile kabul edilen hastaların klinik özelliklerini tanımlamayı hedefledik.

Yöntemler: Ocak 2014 ile Aralık 2015 arasında Dr. Sami Ulus Kadın Doğum, Çocuk Sağlığı ve Hastalıkları Eğitim ve Araştırma Hastanesi'ne toplam 16 kutanöz leyşmanyoz hastası (11 (\%69) erkek and 5 (\%31) kız) kabul edilmiştir. Hastaların bilgileri tıbbi kayıtlarından retrosepktif olarak değerlendirildi.

Bulgular: Hastaların ortalama yaşı 74,3 $\pm 32,3$ ay olarak tespit edilirken (Aralık: 1-10,5 yaş) hastalarda en sık tutuluan vücut bölgesinin yüz ve boyun $(\% 87,5)$ bölgesi olduğu belirlenmiştir. Ciltten alınan örneklerin yaymalarının mikroskobik incelemesinde 9 (\%56) hastada amastigot şekilleri görülmüştür. Ekstemitelerde lezyonu olan $2(\% 12,5)$ hasta intralezyonel meglümin antimonat ile tedavi edilmiştir. On dört hasta sistemik olarak tedavi edilmiştir.

Sonuç: Artan insan hareketleri ve göçler nedeniyle Ankara gibi hastalığın endemik olmadığı bölgelerde de KL vakaları görülebilir. Özellikle, Suriye gibi endemik bölgelerden gelen, ağrısız cilt lezyonları ile başvuran hastalarda endemik olmayan bölgelerde de çocuk hekimleri tarfından KL akılda tutulmalıdır.

Anahtar Kelimeler: Kutanöz leishmaniasis, çocuk, Suriyeli mülteciler

Geliş Tarihi: 03.03.2017

Kabul Tarihi: 22.08.2017

Address for Correspondence / Yazışma Adresi: Ayşe Kaman, E.mail: ayse092003@yahoo.com DOI: 10.5152/tpd.2017.5118

(C) Copyright 2017 Turkish Society for Parasitology - Available online at www.tparazitolderg.org

OCTelif hakkı 2017 Türkiye Parazitoloji Derneği - Makale metnine www.tparazitolderg.org web sayfasından ulaşılabilir. 


\section{INTRODUCTION}

Leishmaniasis is a vector-borne infection that is caused by a protozoan parasite of the Leishmania genus and that occurs worldwide. There are three clinical forms of the infection: visceral, cutaneous, and mucocutaneous. Cutaneous leishmaniasis (CL) is endemic in the southeastern provinces in Turkey and the neighboring Middle Eastern countries (1). Although most patients in Turkey were from Urfa, Adana, Osmaniye, Diyarbakır, Mersin, and Kahramanmaraş provinces before the Syrian civil war, there has been a dramatic increase in the number of $C L$ cases in Ankara due to the forced migration of people $(2,3)$. Although $C L$ had been well controlled and documented in Syria, its incidence has dramatically increased since the beginning of the war; however, there is a lack of documentation (4). Sami Ulus Children's Hospital in Ankara is one of the largest children's hospitals in Turkey. It is a tertiary-care training and research hospital with 416 beds and acts as a referral pediatric center for the entire country. In this retrospective study, the epidemiological and clinical characteristics and treatment modalities of patients with CL who were admitted to the Pediatric Infectious Disease Department of our hospital were examined.

\section{METHODS}

Between January 2014 and December 2015, 16 CL patients were admitted to the Pediatric Infectious Disease Department. Patient data regarding age; sex; nationality; location, number and duration of lesions; and treatment modality were retrospectively recorded. Data was entered to a MS-Excel 2007 programmes and statistical analyses for median age were performed using IBM SPSS Statistics 21.0 (IBM Corp.; Armonk, NY, USA). Samples obtained from the patients' lesions by pediatric infectious disease specialist, were stained with Giemsa and microscopically examined by infectious disease specialty and public health ministry parasitology specialty. The samples were incubated in Novy-Nicolle-McNeal (NNN) media in the reference labarotuary. The patients were treated using intralesional meglumine antimoniate (twice weekly for 3 weeks) or systemic meglumine antimoniate (Glucantime®: $20 \mathrm{mg} / \mathrm{kg} / \mathrm{g}$, intramuscularly, 14 days) or liposomal amphotericin B (Ambisome $\AA$ : $3 \mathrm{mg} / \mathrm{kg} / \mathrm{g}$, once daily for 5 days and subsequently $14^{\text {th }}$ day one dose and $21^{\text {st }}$ day one dose) according to their lesion localization and response to the initial treatment regimen. All patients were monitored weekly by determining liver enzyme levels, complete blood count, cardiac enzyme levels, and amylase levels and by performing electrocardiography for determining side effects. In the early post-treatment period, clinical improvement was defined as the regression of plaque with residual erythema of the affected area for several weeks. Ethics committee approval was not required due to the retrospective nature of this study. The study was conducted in accordance with the principles of the World Medical Association Declaration of Helsinki "Ethical Principles for Medical Research Involving Human Subjects" (amended in October 2013). Informed consent was obtained from the patient whose photographs have been used.

\section{RESULTS}

Sixteen patients who were diagnosed with CL were evaluated. There were 11 (69\%) boys and five (31\%) girls; their ages ranged from one year to 10 years. Their mean age was $74.3 \pm 32.3$ months. The age and gender of the patients are demonstrated in Table 1. Except one patient with congenital heart disease, none of the patients had an underlying disease. Among the 16 patients, two (12.5\%) were Turkish citizens, while 14 (87.5\%) were Syrian refugees. All Syrian refugees were living in Ankara at the time of admission to the hospital, but their cutaneous lesions had started before they left their country. The two Turkish siblings reside in

Table 1. The lesion localization, age, gender and health status of patients

\begin{tabular}{|c|c|c|c|}
\hline & $\begin{array}{l}\text { Age(mo)/ } \\
\text { Gender }\end{array}$ & $\begin{array}{l}\text { Location of } \\
\text { the lesion }\end{array}$ & $\begin{array}{l}\text { The clinical form } \\
\text { of the lesions }\end{array}$ \\
\hline 1. & $41 \mathrm{mo} / \mathrm{M}$ & $\begin{array}{l}\text { Left ear, } \\
\text { right forehead }\end{array}$ & $\begin{array}{l}\text { Crusted ulcerated } \\
\text { plaque on ear } \\
\text { and forehead }\end{array}$ \\
\hline 2. & $59 \mathrm{mo} / \mathrm{M}$ & $\begin{array}{l}\text { Right ear, } \\
\text { left angulus } \\
\text { mandibula }\end{array}$ & $\begin{array}{l}\text { Crusted ulcerated } \\
\text { plaque on ear } \\
\text { and mandibula }\end{array}$ \\
\hline 3. & $103 \mathrm{mo} / \mathrm{F}$ & Nose, right cheek & $\begin{array}{l}\text { Crusted ulcerated } \\
\text { plaque on cheek } \\
\text { and nose }\end{array}$ \\
\hline 4. & $67 \mathrm{mo} / \mathrm{M}$ & Bilateral Cheeks & $\begin{array}{l}\text { Crusted ulcerated } \\
\text { plaque on two } \\
\text { cheeks }\end{array}$ \\
\hline 5. & $90 \mathrm{mo} / \mathrm{F}$ & Left cheek & $\begin{array}{l}\text { Nodular lesion on } \\
\text { left cheek }\end{array}$ \\
\hline 6. & $104 \mathrm{mo} / \mathrm{M}$ & $\begin{array}{l}\text { Right ear, } \\
\text { left cheek and } \\
\text { left leg }\end{array}$ & $\begin{array}{l}\text { Crusted ulcerated } \\
\text { plaque on cheek, } \\
\text { ulcerated nodular } \\
\text { lesion on ear, } \\
\text { ulserative scar on leg }\end{array}$ \\
\hline 7. & $12 \mathrm{mo} / \mathrm{M}$ & Left eyelid & $\begin{array}{l}\text { Crusted papular } \\
\text { lesion }\end{array}$ \\
\hline 8. & $106 \mathrm{mo} \mathrm{F}$ & Left upper arm & $\begin{array}{l}\text { Crusted nodular } \\
\text { lesion }\end{array}$ \\
\hline 9. & $109 \mathrm{mo} / \mathrm{F}$ & Nose & $\begin{array}{l}\text { Crusted ulcerated } \\
\text { plaque }\end{array}$ \\
\hline 10. & $37 \mathrm{mo} / \mathrm{M}$ & $\begin{array}{l}\text { Left neck, left } \\
\text { side of the chin }\end{array}$ & $\begin{array}{l}\text { Crusted nodular } \\
\text { lesions on neck } \\
\text { and chin }\end{array}$ \\
\hline 11. & $56 \mathrm{mo} / \mathrm{M}$ & Right forehead & Ulserative scar \\
\hline 12. & $42 \mathrm{mo} / \mathrm{F}$ & Right forehead & Ulcerated plaque \\
\hline 13. & $59 \mathrm{mo} / \mathrm{M}$ & $\begin{array}{l}\text { Left ankle, back } \\
\text { side of the right leg }\end{array}$ & $\begin{array}{l}\text { Papular lesion on } \\
\text { ankle and leg }\end{array}$ \\
\hline 14. & $79 \mathrm{mo} / \mathrm{M}$ & Left eyelid & Papular lesion \\
\hline 15. & $100 \mathrm{mo} / \mathrm{M}$ & $\begin{array}{l}\text { Nose, back side } \\
\text { of the left leg }\end{array}$ & $\begin{array}{l}\text { Crusted ulcerated } \\
\text { plaque on nose, } \\
\text { papular lesion on leg }\end{array}$ \\
\hline 16. & $125 \mathrm{mo} / \mathrm{M}$ & $\begin{array}{l}\text { Left forehead, } \\
\text { left submandibular } \\
\text { area }\end{array}$ & $\begin{array}{l}\text { Crusted ulcerated } \\
\text { plaque on forehead } \\
\text { and submandibular area }\end{array}$ \\
\hline
\end{tabular}

M: Male; F: Femal; Mo: Month 


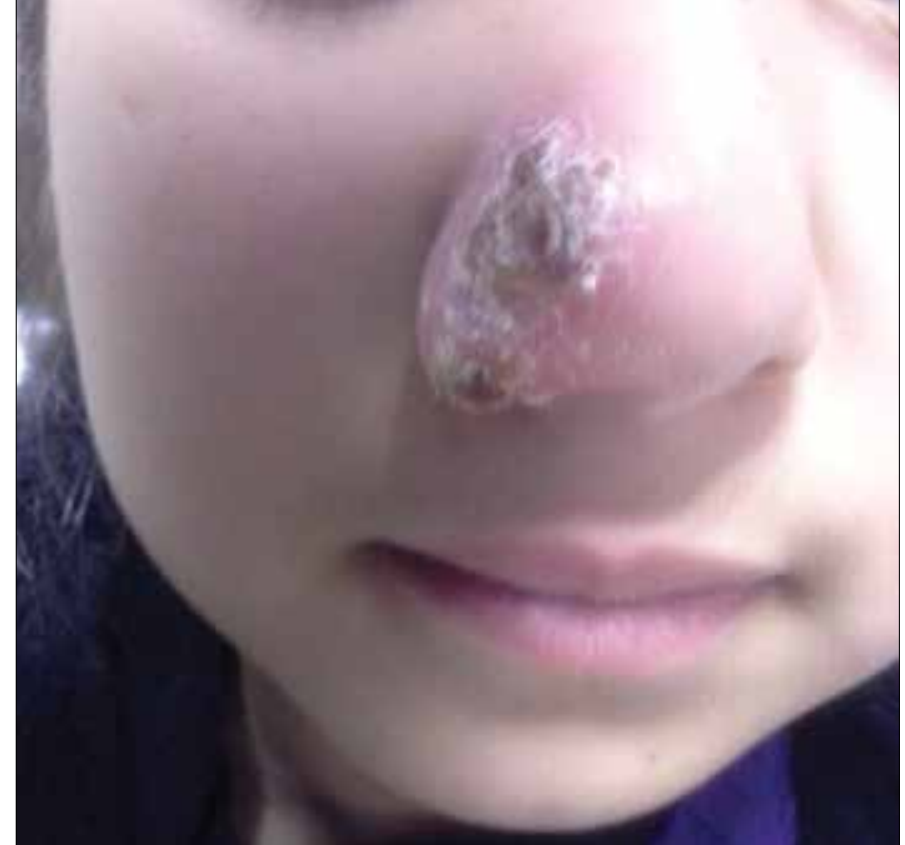

Figure 1. Painless, crusted ulcerated plaque with surrounding hyperemia

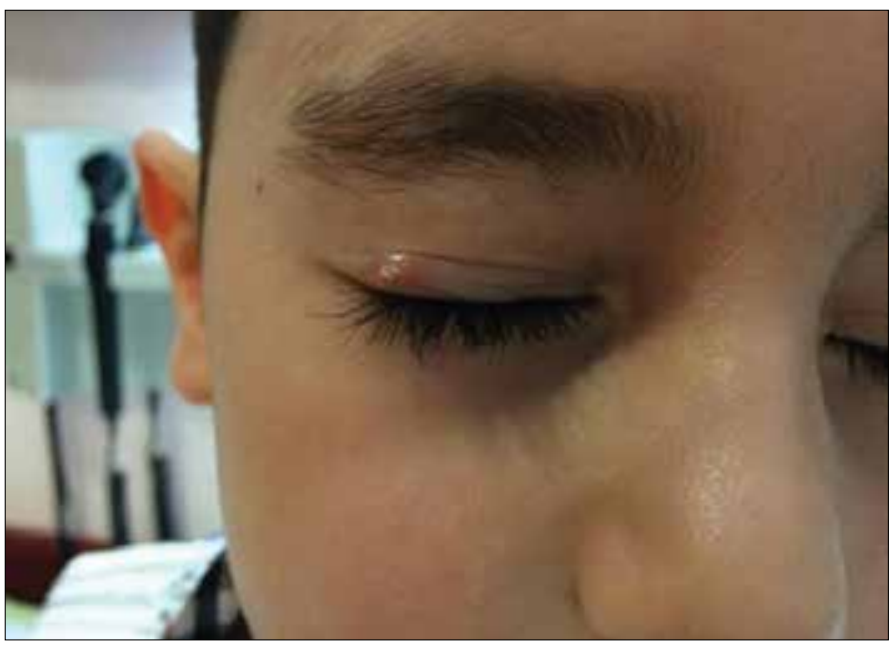

Figure 2. Papular lesion on the right eyelid with surrounding minimal hyperemia

Ankara, but they had travelled to southeastern provinces in Turkey before their complaints began. The study patients expressed that their first lesions had emerged as pimples and then progressed. The duration of progression after the appearance of their first papules to hospital admission was a mean of 10.5 months and ranged from one month to four years. A family history of $C L$ was observed in eight patients (50\%). In total, 26 lesions were identified from 16 patients. Double, single, or multiple lesions were seen in eight, seven, and one patient, respectively. The face and neck was the most commonly involved site [14 (87.5\%) patients]. The eyelid, nose, and ear cartilage were involved in two, three, and three different patients, respectively. The upper and lower limbs were affected in four patients (25\%). Eight patients (50\%) had crusted ulcerated plaques, three had nodular lesions, three had papular lesions, and two had ulcerative scars.
Amastigotes were detected in nine (56\%) patients on skin smears. Cultures of 10 patients (included the patient whose smear tested negative) yielded Leishmania species. The three smear and culture-negative patients were diagnosed with and treated for $\mathrm{CL}$ previously in Syria. One of the remaining three patients was a sibling of the culture-positive patient, and the other two patients were siblings from endemic areas.

Two patients $(12.5 \%)$ who had lesions on the limbs were treat-

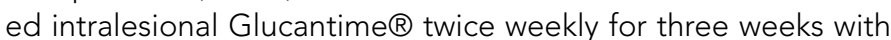
clinical improvement. Due to the involvement of face and neck region (figure 1), 14 patients (87.5\%) were treated with systemic agents in accordance with the World Health Organization (WHO) recommendations. Thirteen of these patients were treated with intramuscular Glucantime ${ }^{\circledR}$ for two weeks. Because of no clinical improvement with Glucantime $\AA$, three of them were sub-

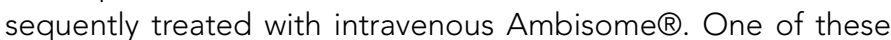
patients showed significant healing, but two patients showed no healing with this alternative therapy. Skin biopsy was planned for the patient who had lesion on the eyelid; however, his family did not accept this intervention and he did not come for follow-up visits (figure 2). Skin biopsy was performed for the patient whose lesion on the nose was enlarged despite this regime. A histopathological examination revealed the presence of granulomatous inflammation in the dermis, and Leishmania spp. was cultured from the skin biopsy specimen. Combination therapy using Ambisome ${ }^{\circledR}$ with miltefosine was planned as an alternative. Unfortunately, he did not come for follow-up visits for six months. Thereafter, spontaneous improvement of his lesion was detected during a later outpatient visit. For the patient who had congenital heart disease as a comorbidity, systemic Glucantime ${ }^{\circledR}$ could not be used as the first-line treatment to avoid potential cardiac side effects. Therefore, intravenous Ambisome ${ }^{\circledR}$ was commenced as the initial treatment, and improvement in his lesion was observed

\section{DISCUSSION}

Globally, children suffer the highest burden of visceral leishmaniasis and CL (5). In a study from Iran, the prevalence rate of childhood CL was $3.0 \%$ (6). The most likely reason for this is that children are exposed to the parasite at an early age. Unlike adults, children are not previously exposed to leishmaniasis; hence, they lack immunity to $C L$. In a recent study from an endemic area in Turkey, 8786 pediatric CL patients were retrospectively evaluated. The authors found that $C L$ is more common in patients in the 6-10-year-old range; 6-10-year-old patients resolve their infection faster and display smaller lesions than 0-5- and 11-15-yearold patients (7). As our study was not epidemiological and was conducted on a relatively small number of patients based on the data obtained from a single tertiary health care facility, we did not consider demographic findings.

Cutaneous leishmaniasis is characterized by the appearance of one or more lesions typically on exposed uncovered parts of the body. The face, neck, arms, and legs are the most commonly involved sites (1). In our study, most patients had lesions on the uncovered parts of their body. In localized $C L$, a typical lesion starts as a papule at the site of inoculation of the parasite after an incubation period of two to six months. The lesion grows over several weeks, and nodules or plaque occur. A scabbed painless 
ulcer develops (1). In our study, all patients presented with painless papules or indurated dry ulcers. In our study, the duration of symptoms before presentation was a mean of 10.5 months. The main reason for this delay in diagnosis may be due to the insidious nature of the disease and the situations arising from the civil war that continues in Syria (8).

Leishmaniasis is a common vector-borne infection worldwide and affects 12 million people in 98 countries or territories, with more than 350 million people at risk (9). The WHO has estimated that approximately 0.2 to 0.4 million new cases of visceral leishmaniasis and 0.7 to 1.2 million new cases of CL cases occur each year worldwide. CL is more widely distributed, with approximately one-third of cases occurring in the Americas, the Mediterranean basin, and western Asia from the Middle East to Central Asia. The 10 countries with the highest estimated case counts are as follows: Afghanistan, Algeria, Brazil, Colombia, Costa Rica, Ethiopia, Iran, Peru, Sudan, and Syria; together, these countries account for 70 to $75 \%$ of the global estimated CL incidence (10). $\mathrm{CL}$ has been a significant public health problem and the most important notifiable vector-borne disease in Turkey. It has been reported that 46.003 new CL cases occurred between 1990 and 2010 in Turkey and that $96 \%$ of these patients were from Urfa, Adana, Osmaniye, Diyarbakır, Mersin, and Kahramanmaraş provinces (2). According to the WHO statistics, the number of cases of CL reported from Turkey in 2013 was 2618 (11).

Syrian refugees in Turkey are under temporary protected status. There are 25 tent camps constructed by the Prime Ministry Disaster and Emergency Management Authority for refugees fleeing from Syria due to war, but most of them (approximately $85 \%$ ) live outside the camps in various cities in Turkey. Health care services for all Syrian refugees are community health care centers and hospitals in our country. These facilities provide free health care for Syrian refugees. However, difficulties from the problems include the presence of unrecorded people due to irregular migration; poor housing and nourishment conditions, particularly outside camps; poverty; and social adaptation and communication problems can result in deficiencies in health care control (12). It is well known that $C L$ is associated with malnutrition, population displacement, poor housing, poverty, a weak immune system, and lack of resources (10). All these risk factors are unfortunately met in the case of the Syrian crisis. Although $\mathrm{CL}$ has been endemic in parts of Syria, mainly Aleppo, for decades, the Syrian conflict and vast population displacement has significantly increased the incidence of the vector-borne disease within Syria and has spread this epidemic to neighboring countries (3). According to the WHO statistics, the number of cases of CL reported from Syria was 71.996 in 2013 (11). The conditions of war exacerbate risk factors for the spread of CL among civilian populations and transform the the $\mathrm{CL}$ into a regional threat. There has been a marked increase in CL incidence in recent years in Turkey; this may be related, in part, to the intense and continuing influx of Syrian refugees to Turkey (9). Our patients were Syrian refugees, except for the two patients who came from the southeastern provinces in Turkey.

The aim of treatment in CL patients is to prevent dissemination and relapses of lesions as well as to cure the disease. Many differ- ent approaches, including local, systemic, and physical therapies (e.g. cryotherapy or thermotherapy), have been used for treating CL. Pentavalent antimonials (intralesional or systemic) remain as the treatment choice for CL. The treatment of CL depends on the involved body site; size, number, and stage of lesions; and health status of the host. Patients with multiple $(>5 \mathrm{~cm})$ or large $(>4 \mathrm{~cm})$ lesions non-responsive to topical treatment or with chronic lesions (>2 years), lesions on mucosal surfaces or on the cartilage tissue, or with lesions that are potentially disfiguring or disabling (on the face, fingers, toes, or joints) should be managed with systemic drugs (1). In our study, most patients were treated with systemic meglumine antimoniate for these indications. No clinically and laboratory side effects were observed in our patients. Children have a higher elimination rate of systemic antimonials than adults. The rate of side effects of systemic meglumine antimoniate in children is similar to that in adults; in general, the drug is well tolerated (13). Liposomal amphotericin $B$ is another option that binds ergosterol and leads to membrane permeability and disrupts the membrane of the parasite. It can be reserved for severe forms of leishmaniasis (visceral or mucosal), lesions resistant to first-line therapy, or HIV-coinfected patients $(14,15)$. In the present study, one patient was treated with amphotericin B as first-line treatment due to patients' comorbidities. Three patients were treated with amphotericin B after administering intramuscular meglumine antimoniate because of treatment failure. As alternative treatment options to standard drugs, miltefosine, pentamidine, fluconazole, and combination therapies, including liposomal amphotericin B plus miltefosine or imiquimod plus meglumine antimoniate, may be considered for treating CL (16). In our study, one patient who did not respond to standard drugs, combination therapy including miltefosine and liposomal amphotericin B was planned. Because of loss to follow-up and the presence of spontaneous healing of the lesion subsequently at a late outpatient visit, this regimen was not used. The natural course of the disease is spontaneous healing over several months/years, with a scar and permanent alterations in skin pigmentation (16). The limitations of our study were the fact that this was not an epidemiological study and that the study was conducted on a relatively small number of patients based on the data obtained from a single tertiary health care facility; therefore, we could not find differences for treatment response according to age.

\section{CONCLUSION}

An increase in human movements might make be possible for $\mathrm{CL}$ to appear in non-endemic provinces such as Ankara. In this case series, most of the patients were Syrian immigrants. As the skin lesions of CL may be mistaken for many conditions, clinicians should be aware of the importance of the epidemiological history, particularly for patients with painless cutaneous lesion(s). A family history of $C L$ is a useful clue for making a diagnosis. Making a rapid diagnosis was possible by directly staining the sample that had been appropriately collected. We found that systemic or intralesional treatment with first line drugs such as systemic antimonials and liposomal amphotericin B according to the lesion location and response to initial treatment regimens was successful in pediatric patients with $\mathrm{CL}$. Furthermore, one patient in our series showed spontaneous healing. 
Ethics Committee Approval: Ethics committee approval was not received due to the retrospective nature of this study.

Informed Consent: Informed consent was obtained from patients who participated in this study.

Peer-review: Externally peer-reviewed.

Author Contributions: Concept - A.K., G.T., MM, Design - A.K., M.M..; Supervision- Z.G.G.A., G.T.; Materials - F.N.Ö. T.A.T.; Data Collection and/or Processing - T.A.T, M.M., Ö.M.; Analysis and/or InterpretationG.T., F.N.Ö., A.K.; Literature Review - F.N.Ö., Ö.M., Z.G.G.A.; Writing A.K., G.T., Z.G.G.A.; Critical Review: F.N.Ö., Ö.M, T.A.T.

Conflict of Interest: No conflict of interest was declared by the authors.

Financial Disclosure: The authors declared that this study has received no financial support.

Etik Komite Onayı: Bu çalışmanın retrospektif niteliği nedeniyle etik komite onayı alınmamıştır.

Hasta Onamı: Bilgilendirilmiş hasta onamı bu çalışmaya katılan hastalardan alınmıştır.

Hakem Değerlendirmesi: Dış bağımsız.

Yazar Katkıları: Yazar Katkıları: Fikir - A.K., G.T., MM; Tasarım - A.K., M.M.; Denetleme - Z.G.G.A., G.T; Veri Toplanması ve/veya İşlemesi - T.A.T, M.M., Ö.M.; Analiz ve/veya Yorum - G.T., F.N.Ö., A.K.; Literatur Taraması -F.N.Ö., Ö.M., Z.G.G.A.; Yazıyı Yazan - A.K., G.T., Z.G.G.A.; Eleştirel Inceleme - F.N.Ö., Ö.M, T.A.T.

Çıkar Çatışması: Yazarlar çıkar çatışması bildirmemişlerdir.

Finansal Destek: Yazarlar bu çalışma için finansal destek almadıklarını beyan etmişlerdir.

\section{REFERENCES}

1. World Health Organization. Manual for case management of cutaneous leishmaniasis in the WHO Eastern Mediterranean Region. Draft 14 2012. Cairo, Egypt. Available from: http://www.emro.who. int/images/stories/zoonoses/Manual_leishmaniasis_edited_MB_ draft_for_Web_1_5_13.pdf
2. Gürel MS, Yeşilova Y, Olgen MK, Ozbel Y. [Cutaneous leishmaniasis in Turkey]. Turkiye Parazitol Derg 2012; 36: 121-9. [CrossRef]

3. Sharara SL, Kanj SS. War and infectious diseases: challenges of the Syrian civil war. PLoS Pathog 2014; 10: e1004438. [CrossRef]

4. Hayani K, Dandashli A, Weisshaar E. Cutaneous leishmaniasis in Syria: clinical features, current status and the effects of war. Acta Derm Venereol 2015; 95: 62-6. [CrossRef]

5. Pace D. Leishmaniasis. J Infect 2014; 69 Suppl 1: 10-8. [CrossRef]

6. Talari SA, Talaei R, Shajari G, Vakili Z, Taghaviardakani A. Childhood cutaneous leishmaniasis: report of 117 cases from Iran. Korean J Parasitol 2006; 44: 355-60. [CrossRef]

7. Aksoy M, Doni N, Ozkul HU, Yesilova Y, Ardic N, Yesilova A, et al. Pediatric Cutaneous Leishmaniasis in an Endemic Region in Turkey: A Retrospective Analysis of 8786 Cases during 1998-2014. PLoS Negl Trop Dis 2016; 10: e0004835. [CrossRef]

8. Saroufim M, Charafeddine K, Issa G, Khalifeh H, Habib RH, Berry A, et al. Ongoing epidemic of cutaneous leishmaniasis among Syrian refugees, Lebanon. Emerg Infect Dis 2014; 20: 1712-5. [CrossRef]

9. Özbilgin A, Çulha G, Uzun S, Harman M, Topal SG, Okudan F, et al. Leishmaniasis in Turkey: first clinical isolation of Leishmania major from 18 autochthonous cases of cutaneous leishmaniasis in four geographical regions. Trop Med Int Health 2016; 21: 783-91. [CrossRef]

10. World Health Organization. "Leishmaniasis". Available from: http:// www.who.int/gho/neglected_diseases/leishmaniasis/en/.

11. World Health Organization. "Leishmaniasis: number of cases of cutaneous leishmaniasis reported data by country". Available from: http://apps.who.int/gho/data/view.main.NTDLEISHCNUMv.

12. AFAD, (2015), "Suriye Afet Raporu". Available from: https://www. afad.gov.tr/TR/IcerikDetay1.aspx?ID=16\&lcerikID=747.

13. Layegh P, Khademi Z, Afzal Aghaee M, Moghiman T. Systemic Meglumine Antimoniate in Cutaneous Leishmaniasis of Children: Clinical and Laboratory Complications. J Pediatric Infect Dis Soc 2015; 4: 356-8. [CrossRef]

14. Crowe A, Slavin J, Stark D, Aboltins C. A case of imported Leishmania infantum cutaneous leishmaniasis; an unusual presentation occurring 19 years after travel. BMC Infect Dis 2014; 14: 597. [CrossRef]

15. Lopes L, Vasconcelos P, Borges-Costa J, Soares-Almeida L, Campino L, Filipe P. An atypical case of cutaneous leishmaniasis caused by Leishmania infantum in Portugal. Dermatol Online J 2013; 19: 20407.

16. Al-Natour SH. Update in the treatment of cutaneous leishmaniasis. J Family Community Med 2009; 16: 41-7. 